\title{
Intellectual Property Rights Enforcement in Nigeria: A Prop for Music Industry
}

\author{
Ebele V. Ojukwu \\ Nnamdi Azikiwe University, \\ Awka, Nigeria
}

\author{
Young Sook Onyiuke \\ University of Lagos, \\ Lagos, Nigeria
}

\author{
Chinyere C. Esimone \\ Nnamdi Azikiwe University, \\ Awka, Nigeria
}

The right of anybody over his/her creative output is an exclusive one. Artistes encounter various kinds of encumbrances in their bid to make a living out of their creative abilities as a result of infringement and some other ugly practices which undercut the economic benefit of the intellectual property of these talented artistes. There is no doubt that the copyright law has been developed and established in Nigeria, but the strategies that have been put in place to ensure its effective implementation and the opportunities provided for the copyright owners to maximally exploit their rights are in question. This paper seeks to address the need for the Nigerian Copyright Act to undergo reformation in order to enhance the protection which the law purports to afford the owners or authors of the copyrighted works in the music industry. The paper also critically examined the strategies already in place and what needs to be done towards making the Copyright Act more acceptable and beneficial to all intellectual property owners which invariably will encourage the spirit of creativity and productivity in the music industry. The investigation applied historical and other related resource materials as working tools. The paper concludes by suggesting that Nigerian government should form a formidable force through public enlightenment, collaboration among agencies, and with the copyrights owners' cooperation in order to enhance effective enforcement of intellectual property rights which will go a long way in boosting the music industry in Nigeria.

Keywords: music industry, intellectual property, copyright law, enforcement and enlightenment

\section{Introduction}

Music industry seems to be the most widely practised and most accessible of all the arts in the entertainment industry. It forms an important part of many cultural and social activities. Music plays a major role in other arts considering the fact that people use music for several purposes. R. C. Okafor and C. U. Okafor (2009) illustrated this clearly and wrote "Where there are great artistes of popular music, the entertainment industry, film management services, public relations and advertisement services naturally function actively" (p. 20). Walter (1996) (as cited in Okwilagwe, 2002) early in time stated that:

Opera combines singing and orchestral music with drama. Ballet and other forms of dancing need music to help the dancers with their steps and evoke the atmosphere. Film and TV drama use music to help set the mood and emphasise the action. (p. 106)

Ebele V. Ojukwu, Ph.D., Lecturer I, Department of Music, Faculty of Arts, Nnamdi Azikiwe University.

Young Sook Onyiuke, Ph.D., associate professor, Department of Creative Arts (Music), Faculty of Arts, University of Lagos.

Chinyere C. Esimone, Ph.D., Lecturer II, Department of Music, Faculty of Arts, Nnamdi Azikiwe University. 
Music industry and whatever that comes under it cannot operate outside the control of individuals. It is being produced by human intelligence. The efforts of these great intellectuals are being exploited, frustrated, and deprived of their entitlements due to the activities of infringers who rip them off their benefits, thereby, preventing the industry from rapid financial growth and development. Adeleye (2013) lamented that:

The incidence of infringement and violation of intellectual property rights especially in the nature of counterfeiting and piracy has been on the increase in Nigeria. Activities of the infringers/counterfeiters have ripped off many producers, manufacturers, artists, marketers, and stakeholders of the benefit of their creativity. (p. 2)

An infringement of copyright occurs when any other person without authorization does anything which only the owner of the creative work has the right to do. It is an indispensible factor for the existence of the music industry in any organised society. It is indeed a cornerstone and one major pillar in the sustenance of the entertainment industry in general. Intellectual property infringement should be seen from a moral background for one to fully understand the magnitude of damage and injustice being melted out to intellectual property owners in Nigeria. Notwithstanding the fact that the Nigerian constitution dedicates a whole chapter (Chapter 68) to Copyright Act, its enforcement still remains a dream yet to come true. Nigeria is a nation that boasts of world-class artistes. Yet, the Nigerian music industry is plagued with abusers of the copyright law. The industry is now synonymous with piracy and intellectual property infringement. Artistes in Nigeria have resorted to stage performances in big cities of the nation as their main source of income since little or no income is realized from the sale of music compact discs. This in turn can be blamed on the widespread and uncontrolled use of the Internet as a medium for data exchange. An album can be released in the morning at Abuja and downloaded in Lagos by evening. Noteworthy also is the fact that the widespread use of the Internet and the increasingly sophisticated technology synonymous to it has made it very difficult for regulatory bodies to make tangible impact. These violations neither respect national borders nor geographical boundaries. While it might be seriously enforced in developed countries, it is still treated with a laizzez-faire attitude in developing countries, while it is severely punished in Europe, it would seem that nobody cares about who downloads what in many countries in Africa. The Nigerian music industry produces an average of 550 albums of different types of music annually, and an estimated 1,200 concerts and musical shows that take place every year which account for a combined annual turnover of US\$105.5 million. Although statistics on the pirated amount of materials are not very clear, a visit to any popular market in the country will reveal its parasitic effect on the music industry and the Nigerian economy at large (Daniel, 2010).

Copyright abuse does not just happen in Nigeria, as a matter of fact, it happens all over the world. In the year 2000, US heavy metal band "Metallica" sued the Internet company "Napster" for allowing unrestricted distribution of their song "I Disappear" over their online network. The band won the law suit while Napster was ordered to keep track of the activities on its network and to restrict infringing materials. Napster was not able to comply with these directives and thus had to close down its services in July 2001. The company later became bankrupt and was sold to a third party (Napster, n.d.). This is just one out of many cases where the law prevails. It was noted in the Nigerian Vanguard Newspaper that Nigeria was the first African country to undertake the comprehensive copyright reform as did China, India, and Brazil (Elebeke, 2013). The Nigerian Copyright Commission (NCC) boss also noted that there was an improved international rating of Nigeria in the global fight against piracy. It was also revealed that 31 copyright cases have been prosecuted in 2012 and that the commission also destroyed by public burning 722 million units of various categories of copyright infringing 
products impounded between 2007 and 2011, estimated at NGN6.5 billion (\$40.625 million) (Elebeke, 2013). All these recorded feat notwithstanding, the rate of piracy in Nigeria is still on the high side.

This paper seeks to address the place of the Copyright Act in the bid of protecting the rights of all groups involved in enhancing the music industry in Nigeria. For the purpose of this paper, intellectual property right, though broader than copyright in terms of application, may be used interchangeably and still connoting the same meaning.

\section{Conceptual Framework}

\section{Intellectual Property Right/Copyright}

The intellectual property right is an umbrella term for various legal entitlements, which attach to certain names, written and recorded media, and inventions. It refers broadly to the creation of the human mind and it is assuming increasing importance in every facet of life today unlike what it used to be before the advent of modern science and technology. There are two branches of intellectual property, namely, copyright and industrial property. Copyright deals primarily with literary, musical, and artistic creations while industrial property right deals with patents, trademarks, and industrial designs (Adeleye, 2013). Intellectual property is an intangible form of property, as opposed to personal property or real property, which is concrete and much more easily defined. It is the result of the creation of the brain or the mind, which is then manifested or interpreted in a form that has a physical dimension and possesses exclusive property right. Examples include images, symbols, names, designs, and literary and music works. Intellectual property broadly includes such areas as copyright, trademarks, patents, and industrial designs.

Chandra (2004) defined intellectual property as "property from original thought protected by law: Original creative work manifested in a tangible form that can be legally protected, example by a patent, trademark or copyright" (p. viii). Adeleye (2013) further noted that intellectual property "is an intangible asset because it has no physical form; it is a category of intangible right protecting commercially valuable works, products and services of the human intellect" (p. 2). The area of law that deals with and oversees the creation of intellectual property patents, copyrights, trademarks and trade secret laws, the protection of intellectual property rights; and the legal pursuit of those who infringe on another's right to his/her intellectual property is known as Intellectual Property Law.

Copyright is defined as "the exclusive and assignable legal right, given to the originator for a fixed number of years, to print, publish, perform, film or record literary, artistic or musical material" (Retrieved from http://www.oxforddictionaries.com/definition/english/copyright). It also refers to the reserved or exclusive right given by law to the creator of a literary work as regards the use, reproduction, and exploitation of his/her created works for economic or commercial purpose. Okafor (2002) opined that "Copyright is the moral and financial rights creators have over their works" (p. 114). The New International Webster's Comprehensive Dictionary of the English Language (2010) defines copyright as "the exclusive statutory right of authors, composers, playwrights, artists, publishers, or distributors to publish and dispose of their works for a limited time" (p. 288).

\section{Music Industry}

An industry consists of various specialists who make up that industry. "Music industry involves the production, distribution, and sale of music in a variety of forms as well as the promotion of life musical 
performance" (Miller, 2003). The industry connotes several activities and organizations by different artistes working towards specific ends but united in the common objective of processing and distributing musical product to the consumer for the purpose of profit-making. The business and creative sides of the music business are inextricably linked - no matter how proficient one is creatively, he/she needs to think and operate like a business in order to remain successful.

Creativity is the bedrock of every civilization and the truth of the assertion cannot be more obvious than the rapid changes that have been brought about in the wake of the Internet and the digital revelation. The potentials and possibilities available and various platforms are limitless. (NCC, n.d.)

Okafor (2005) opined that "The musical industry moves a lot of money in any country" (p. 14); even outside Nigeria. He noted that everybody that was associated with the production and marketing of music by "the Beatles" was virtually a millionaire. Music industry is essential to the life of or existence of social life of any country. It situates at the heart of the country's entertainment industry. The industry, therefore, becomes a fertile ground for tapping and distributing the talents and creativity of the musicians. Music industry is the totality of the several groups involved in music production that work together towards a common objective of making money through music distribution. R. C. Okafor and C. U. Okafor (2009) early in time noted that:

The system is an aggregation of several activities and organisations working towards specific ends but united in the common objective of distributing music for profit. As a result, the beneficiary is several centres - the composer, the artist, the industrialist, the agent, the producer, the marketer, and the user. The implicated services would include advertising, banking, promotional services and public relations. The industry therefore offers opportunity for several disciplines, talents, organizations, and persons. The trained or talented or qualified person can position himself in any of the strategic arms of the industry. (pp. 19-20)

\section{The Strategies so Far in Place}

The NCC is the body responsible for administering, regulating, and enforcing copyright in Nigeria. This body has its national headquarters and its zonal offices in the six geo-political zones in Nigeria. It operates under the supervision of Ministry of Culture and Tourism. The body has its work cut out to gradually overcome attitudes ingrained in society from youth to policy-makers themselves. The NCC Decree No. 61 of 1970 was the first indigenous legal institution regulating issues relating to copyright in Nigeria. This decree was promulgated just after the Nigerian civil war ended but salient provisions in the law did not foresee the rapid socio-economic development, as well as influx of product of advanced technology upsurge (NCC, n.d.).

However, notable feats have been achieved by the NCC, worthy of note include confiscation of an estimated NGN2.5 million worth of suspected pirated books belonging to different copyright owners and arresting of seven suspected pirates during an enforcement action carried out at Federal Secretariat Complex, Abuja and its environs on September 6, 2013, the raid on the notorious Alaba International Market, Ojo, and the Isashi area of Lagos in a bid to burst a new trend of importation, marketing, and exploitation of high-tech equipment for hacking or piracy of encoded broadcast signals, mostly of Digital Satellite Television (DStv) channels. On August 27, 2013, acting on intelligence and surveillance reports, copyright inspectors led by Mr. Charles Amudipe, Uyo Liaison Officer backed by armed policemen from Zone 6 Calabar, stormed the book stands of the booksellers and arrested five suspects engaged in the sales of suspected pirated copies, books worth NGN100,000 were impounded (Planning Research and Statistics Department, n.d.). The NCC says that it 
prosecuted 31 copyright cases in 2012, 26 of which were criminal convictions of pirates and five civil suits. Also, a total of 85 suspected pirates were arrested and pirated goods worth NGN4.38 billion were seized (Elebeke, 2013).

It is pertinent at this juncture to see what the Copyright Act Chapter 68, law of the Federation of Nigeria, 1990 which has been amended by Decree No. 98 of 1992 and Decree No. 42 of 1999 respectively say concerning the Copyright Act:

An act to make provisions for the definition, protection, transfer, infringement of and remedy and penalty thereof of the copyright in literary works, musical works, artistic works, cinematograph films, sound recordings, broadcast, and other ancillary matters. (Federal Republic of Nigeria (FRN), 1990)

Copyright law went on to state in the part one of the copyright that: subject to the section, the following shall be eligible for copyright: literary works; musical works; artistic works; cinematograph works; sound recording; and broadcasts. Furthermore, a literary, musical, or artistic work shall not be eligible for copyright unless:

1. Sufficient effort has been expended on making the work to give it an original character;

2. The work has been fixed in any definite medium of expression now known or later to be developed, from which it can be perceived, reproduced, or otherwise communicated either directly or with the aid of any machine or devise. (FRN, 1990)

Music industry is affected by piracy matters on a regular basis; from artist contracts, recording and music publishing agreements to copyright law, name protection, and business organization. After the intellect demanding task of making music, it is not only modest but also legal that the music person gets all the benefits associated with his/her musical work. Legal aspects of the music business examines all the legal issues artists, musicians, engineers, and producers encounter when building their careers, and present a focused look at the important legal changes that have evolved as a result of the shift in the music business landscape. Okafor (2002) grouped the operational environment of the copyright law into three, namely: (a) legal environment; (b) social environment; and (c) administrative environment.

In the legal environment, the main provision of the Copyright Act is concerned with the expression of ideas as in literary, artistic, musical, cinematographic films, sound recordings/films and scientific creation and the legal protection of the expression from unauthorised use (Asein, 1994). Copyright is usually indicted with the international agreed letter " $\mathrm{C}$ " in a circle on the title page or at the end. Ekpo (1994) opined that the details of the bundle of rights contained in any particular copyright depend on whether the work is a literary or musical work, an artistic work, a cinematography film, or a sound recording or broadcast. The right to control covers the whole, whether substantial part of the work in its original form or any form recognisable derived from the original.

Throughout the century, the intellectual property owners as well as the government have put several strategies in place to ensure the protection and promote the careers of the right owners. The war has been fought at both national and international levels. Though some of these strategies yielded good results, but they are not quite encouraging compared with the height of piracy in the country today. Professional Musicians Association of Nigeria (PMAN) members and other artists and artistes cannot keep track of the sale and circulation of their works. Broadcast media on their part cannot monitor their compliance with copying and performing rights. At the international level, the World International Property Organization (WIPO) stipulated 
the provisions of the copyright laws in order to bring them to bear with the day to day processes of the different areas of their relevance. All these notwithstanding, the copyright enforcement faces several administrative hurdles in Nigeria. It requires more effort to extract their genuine and beneficial collaboration due to insufficient data base with which to operate.

\section{Factors Militating Against an Effective Enforcement of Copyrights in Nigeria}

Piracy, which is the illegal reproduction of another person's work of art for one's economic gain is the most formidable force which the music industry in the Nigerian economy is contending with. Piracy has threatened the existence of the music industry. The music industry, according to Miller (2003), "has met with an ineffective strategy based around copyright enforcement, the revenues of the record labels have fallen by more than 60 percent, yet there was nothing inevitable about this tale of decline".

Steve Rhodes gave a reflection on Nigerian music industry and opined that before the Nigerian Civil War, the music industry was booming with a lot of creativity going on but after the war, a lot of people who were involved in the music scene at that time disappeared (Oyebade, 2011). Then, the new trend was a band of copy cats that are unable to generate new ideas and concepts in music. This has to a large extent dwindled the creativity and financial strength of those in the music industry and so, there was difficulty in developing a growth pattern in the music industry. Okafor (2005) asserted that "The artistes get no royalties for their works and therefore cannot improve their lot through their own work in the economic system of their country" (p. 16). He further lamented that:

Nowadays, too many gramophone records are put on audio cassettes and either sold or played even in public much against the Copyright Decree (FRN, 1999) in force in the country and much against the International Mechanical Copyright Law or the Mechanical Copyright Convention. Nigeria had, in the year 1982, a total of about 20 million units involved in piracy. (Okafor, 2005, p. 16)

Several efforts have been made by different agencies towards fighting the menace of piracy in Nigeria. Both the government through its agency and the property owners themselves through their organization have put in a lot of energy in the fight, but due to the fact that piracy like a cankerworm has eaten deep into the vast areas of the country, much still need to be done. The WIPO in their WIPO Magazine (Sylvie, 2008) gave a detailed account of the strategic action of the NCC war against piracy in Nigeria. The commission's anti-piracy initiative was implemented on three strategic platforms, namely: (a) public enlightenment and education; (b) enforcement; and (c) rights administration. The attack of the NCC no doubt made some progress in their Strategic Action Against Piracy (STRAP) and the Copyright Litigation and Mediation Programme (CLAMP) action, but it was noted that the problems caused by the vastness and informality of Nigeria's internal market place are not the only complications when it comes to fighting piracy. Other factors against ineffectiveness of enforcement can be attributed to lack of human resources; funding and practical experience in intellectual property enforcement of relevant officials; insufficient knowledge on the side of right holders and the general public concerning their rights and remedies; and systemic problems resulting from insufficient national and international coordination, including lack of transparency (Adeleye, 2013). The commission enumerated other problem areas as follows:

1. Cross-borders issues arise with Nigeria's four neighbours: Benin, Chad, Cameroon, and Niger;

2. Limited resources must be optimised and field work targeted for the best results; 
3. There is a general lack of awareness of intellectual property laws and regulations. (Sylvie, 2008)

It is disheartening that despite all the efforts and several attacks made by the NCC anti-piracy initiatives with STRAP and CLAMP and other agencies in Nigeria towards waging war against piracy, the level of piracy is still high, up to " $58 \%$ of all copyrighted works in Nigeria" (Sylvie, 2008). Poverty, high cost of originals, greed and profitability, and weak law enforcement have been enumerated as the causes. Others include high level of ignorance about the copyright system amongst right owners, enforcement agencies, and other officials who were hitherto presumed to be sufficiently informed.

\section{Strategies for Making the Copyright System More Beneficial in the Music Industry}

Tackling the problem of piracy in any nation especially in Nigeria has to start with enabling law by the National Assembly who will spell out the composition of the copyright commission and the punishment to be melted out to the offenders. It seems that the best strategy so far to be adopted in respect to curbing the menace of piracy in Nigeria is through massive morality education which will be geared towards promoting change of attitude in the citizens from childhood to adulthood. Nigerians should be made to understand that piracy is an offence and that no one has the moral justification to indulge in it. This can be achieved through the following agencies: home (parents to children), government (formal school, workshops, seminars, organizations, and public enlightenment), and other advisory channels.

The fight would have to start from the grassroot of the society; the family. Parents need to teach their children that it is morally wrong to download music illicitly or purchase pirated works. The children have to grow up with this notion. Intellectual property education content should be incorporated in the civic education and social studies curriculum right from the primary level to the secondary level of Nigerian education system. Copyright law should be made a compulsory course for certain departments in the Nigerian universities. Copyright clubs should be created in schools to "provide students with bite-size bits of information at a time on copyright and dangers of infringement, so that they feel concerned with copyright issues" (Sylvie, 2008). The NCC must cultivate the members of the public to give information to them. Schools too have a responsibility to control the use of their Internet facilities. The government perhaps has the most important role to play here. The government will have to spend more money in the fight, campaigns against illicit or "free" downloads will have to be carried out, arrests will have to be made, and the message will have to be loud and clear. Internet service providers will have to monitor their subscribers and also block Websites that allow illegal redistribution of copyright materials. A good example is the recent Internet censorship promulgated by the Chinese government which gives the government more control of materials circulating on the Internet and keeps tabs on them. There is a serious need for the NCC to step up its public enlightenment and right owner education programme in other to sensitize stake holders on their right and the best methods of addressing the copyright piracy.

To serve as a deterrent to violators, the following are suggested:

1. The NCC in company with armed security agents should ensure regular raids to the markets (such as Alaba International Market, Lagos, Iweka Road Electronic Market, Onitsha, to mention but a few) and factories or buildings where the pirated works are produced seizing and destroying pirated works;

2. The judiciary must cooperate with the NCC and security agents, so that if an offender is arrested, he/she must not be let off the hook on technicalities; maximum punishment must be melted out;

3. Defaulters must be prosecuted, ensuring they go to jail for their actions or pay heavy fine as an alternative. 


\section{Conclusion}

Having looked at the copyright problem from all facets, the fight to stop it should be fought on a rather moral ground. The Internet has come with its good and bad. It has evolved into something we cannot do without, something we cannot do away with. A fight for reinstitution and proper enforcement of the copyright law in the music industry must be fought while being armed with the technological backup to control music transfer over the Internet. Nigeria has a pretty good copyright law but the non-evolving natures of our laws tend to militate against the fight. Most of these laws were made at a time when current day developments were not very familiar to our legislators. Our laws are in dire need of amendments. Having identified the main factors militating against the fight as lack of public awareness, shortage of funds/computer facilities, etc., it is worthwhile to note that regulatory bodies should stand at the battlefront: The NCC is a good example of such body; its functions include carrying out raids, seizing items established to be pirated, and arresting and arraigning perpetrators. The government should also be prepared to dish out tough sentences to those convicted. The judiciary should also sit up; cases pertaining to copyright abuse should not be delayed as it frustrates those that were offended.

We believe that if the ideas generated in this paper would translate into actions and results, the music industry in Nigeria will reap its harvest.

\section{References}

Adeleye, A. I. (2013). Intellectual property rights enforcement in Nigeria: Regulatory agencies to the rescue. Retrieved August 6 , 2013, from http://www.nlipw.com

Asein, J. O. (1994). The Nigerian Copyright Act with introduction and notes (A publication of the Copyright Council). Ibadan: Sam Bookman.

Chandra, R. (2004). Issues of intellectual property rights. Delhi: Isha Books.

Daniel, G. (2010). Agencies intensify efforts to "export" Nigerian entertainment industry. Retrieved September 23, 2013, from http://nigeriansabroadlive.com/agencies-intensify-efforts-to-export-nigerian-entertainment-industry/

Ekpo, M. F. (1994, April 27). Evolving an effective remuneration system for Nigerian musicians through copyright. A lecture organised for Musicians by Samnice Limited, Banquet Conference Hall, National Theatre Iganmu, Lagos.

Elebeke, E. (2013, January 30). Copyright commission impounds N4.3bn pirated goods in 2012. Vanguard. Retrieved August 6, 2013, from http://www.vanguardngr.com/3013/01

Federal Repubic of Nigeria (FRN). (1990). Copyright act chapter 68 laws of the Federation of Nigeria. Retrieved September 4, 2013, from http://www.nigeria-law.org/CopyrightAct.htm

Federal Republic of Nigeria. (1999). The Nigerian Copyright Law (Amendment) Decree (No. 42). Lagos: Federal Government Press.

Miller, K. (2003). Music industry dictionary of American history. Retrieved September 4, 2013, from http://www. encyclopedia.com/doc/1G2-3401802800.html

Napster. (n.d.). In Wikipedia, the free encyclopedia. Retrieved September 15, 2013, from http://en.wikipedia.org/wiki/Napster

Nigerian Copyright Commission (NCC). (n.d.). Director-general's message: I am glad to have you. Retrieved September 4, 2013, from http://www.copyright.gov.ng

Okafor, R. C. (2002). Copyright enforcement and nation building: Environment, problems and opportunities. In E. Idolor (Ed.), Music in Africa facts and illusions (pp. 113-118). Ibadan: Stirling-Horden.

Okafor, R. C. (2005). Music in Nigerian society. Enugu: New Generation Books.

Okafor, R. C., \& Okafor, C. U. (2009). Music and national development in Nigeria. Enugu: New Generation Books.

Okwilagwe, A. O. (2002). African traditional music and the concept of the copyright law. In E. Idolor (Ed.), Music in Africa: Facts and illusions (pp. 105-112). Ibadan: Stirling-Horden.

Oxford Advanced Learner's Dictionary. (1948). Copyright by Oxford. Retrieved June 29, 2015, from http://www.oxforddiction aries.com/definition/english/copyright 
Oyebade, D. (2011). Last of the octogenarians (?): An encounter with elder Steve Rhodes of Nigeria. Afro Beat Journal, 2. Retrieved June 9, 2015, from http://afrobeatjournal.org/en/Issue_2_Spring_2011/5/148/Last-of-the-Octogenarians-\%28\%29 -An-Encounter-with-Elder-Steve-Rhodes-of-Nigeria-Scholarly-Articles-Nigerian-Oyebade-Dosunmu.htm

Planning Research and Statistics Department. (n.d.). NCC impounds N2.5 million books, arrests seven suspected pirates. Retrieved September 23, 2013, from http://copyright.gov.ng/index.php/news-and-events/231-ncc-arrests-5-seizesn100-000-worth-suspected-pirated-law-books-at-nba-conference

Sylvie, C. (2008, September). STRAP and CLAMP-Nigeria Copyright Commission in action. World Intellectual Property Organization (WIPO) Magazine. Retrieved February 4, 2009, from http://www.wipo.int/wipo_magazine/en/ 2008/05/article_0009.html

The New International Webster's Comprehensive Dictionary of the English Language. (2010). Naples, F.L.: Typhoon Media Corporation. 